\title{
WAS AGRICULTURAL DISTRESS IN THE 1930's A RESULT OF LAND SPECULATION DURING WORLD WAR I? THE CASE OF IOWA
}

\author{
by Lowell K. Dyson \\ Blacksburg, Virginia
}

Professor Dyson was born in Adel, Iowa and obtained his undergraduate degree from Iowa State University. He received his $M$. A. and Ph. D. from Columbia University as a Lydia C. Roberts Fellow, and has taught at the Universities of Iowa and Maryland respectively. Professor Dyson is presently an Assistant Professor at Virginia Polytechnic Institute and Universi'y, Blacksburg, Va.

During the winter of the Great American Interregnum, between the election of Franklin Delano Roosevelt in Nov. 1932 and his inauguration four months later, an already stunned nation examined the fabric of its society for the faults which had brought on the worst depression in history. Critics found a plenitude of targets-capitalism, the banking system, the stock market, and sometimes even those who had suffered most, the unemployed and the dispossessed. Indeed, the pangs of self-accusation gnawed at a host of the jobless who felt that the Twentieth Century world had shunted them aside, stamped with the label, "rejected." Something of the same was true in rural America where millions of farmers either had already lost or stood in imminent danger of losing their land. Were these men the victims of their own past errors? This study seeks the answer in one rich agricultural state, Iowa, but the findings have significance for farming areas throughout the nation.

According to one estimate, Iowa farms in 1932 carried a mortgage burden of $\$ 1,082,882,000{ }^{1}$ This figure was slightly lower than that of 1930 when the United States Department of Agriculture indicated that farm debt in the Hawkeye State amounted to 11.9 per cent of the total for the nation, leading the second state, Illinois, by almost a half billion dollars. ${ }^{2}$ 
By 1932 the number of forced sales averaged more than seventeen a day, and outraged Iowa farmers began a protest movement against any further foreclosures, which sometimes spilled over into violence. ${ }^{2 a}$

The sad plight of many farmers awakened the attention of the nation and led eventually to the passage of relief legislation by the Roosevelt administration, but there existed widespread suspicion in 1932 and 1933 that rural avarice had precipitated the whole problem. William Allen White, for example, showed little sympathy for his neighbors who had overexpanded during the boom times of World War I, and Josephine Herbst found during a tour of the Midwest that many small town people felt that farmers were getting exactly what they deserved for having speculated in land during the period of high prices of 1918 and 1919. The dean of Iowa journalists, Harvey Ingham, told his readers, "The fact is that the farm west has been using land too much as basis of speculation and far too little as the home of the farm." Others agreed. ${ }^{3}$

Probably no historian would contest the belief that there had been a good deal of gambling in land. When the commodity price index rose from the prewar average of 100 to 181 in 1917 and 211 in $1920,{ }^{4}$ land values were bound to follow. By 1920, Iowa land was selling for 213 per cent of prewar prices. $^{5}$ The area of encumbered land increased between 1915 and 1920 from 38 to 47 per cent of the total, and the estimated farm mortgage debt climbed to $\$ 1,500,000,000$ from the earlier $\$ 685,000,000{ }^{6}$ Disregarding the warnings of a few Cassandras, many farmers confidently predicted that land values would soon triple and quadruple. ${ }^{7}$ For a time it seemed, according to the managing editor of Wallaces' Farmer, that speculators were so busy "sitting around the livery stable and playing games with options," that no time remained to hitch up a team for field work. ${ }^{8}$

Obviously then, land did become an article of speculation from 1917 through 1920. This meant that many purchasers - often non-farmers-bought their acres for the express purpose of profiting from resale at an appreciated price. They regarded the money made in normal farming operations 
as a minor factor in their investments. At the same time, many tenants sought to take a step up the agricultural ladder by becoming owners while small holders hoped to enlarge their operations to take advantage of the efficiencies offered by new methods and machinery. The problem is to distinguish between these modest aspirations and the operations of the gamblers, and to determine whether farmers in 1932 and 1933 were suffering for their greed of a dozen or so years earlier.

The boundary line between serious investment and speculation has no exact location, and the definition is obscure. There are at least three indicators, however, which if used carefully can suggest answers. Speculators operate on the risk capital of others; therefore, they often need to go beyond first mortgages into a series of junior mortgages; their funds come from sources uninhibited by legal limits or cautious tradition; and their mortgage debt per acre is likely to be quite high.

Conservative lenders recognized first mortgages as sound investments in most cases. Second, third, and fourth mortgages rest on surety far less firm and on the probability of a high level or risk. In 1915, a year of agricultural stability, junior mortgages made up only 11 per cent of all loans in a study of farms in thirteen representative Iowa townships. During the next six years, while first mortgages slightly more than doubled in value - consistent with the general rise in the price index - junior mortgages increased almost fourfold until they made up about 19 per cent of loans outstanding. In the next few years speculators found their purchases far less attractive as the result of the drop in commodity prices, and by 1925 the value of junior mortgages had fallen off by a third. Those who had gambled on the constant appreciation in land values were seeking other and greener pastures. At the end of the decade the ratio of junior debts to the total was less than in 1915. Farm owners had liquidated a major portion of their second, third, and fourth mortgages prior to the onset of the Great Depression and had cut them further before the organized anti-mortgage campaigns of the 1932-33 winter. ${ }^{\circ}$ 
TABLE I.-Estimated Junior Mortgage Debt in lowa for Selected Years

\begin{tabular}{crrc}
\hline $\begin{array}{c}\text { Year } \\
\text { (Dec. 31) }\end{array}$ & $\begin{array}{c}\text { Total Mortgage } \\
\text { Debt }\end{array}$ & $\begin{array}{c}\text { Junior Mortgage } \\
\text { Debt }\end{array}$ & $\begin{array}{c}\text { Junior Mortgages } \\
\text { as per cent of total }\end{array}$ \\
\hline 1915 & $685,114,000$ & $77,189,000$ & 11.3 \\
1920 & $1,499,577,000$ & $262,848,000$ & 17.6 \\
1921 & $1,609,744,000$ & $300,699,000$ & 18.7 \\
1925 & $1,531,192,000$ & $210,225,000$ & 13.7 \\
1930 & $1,265,456,000$ & $115,785,000$ & 9.1 \\
1932 & $1,082,882,000$ & $85,824,000$ & 7.9 \\
(Oct. 15) & & \\
\hline
\end{tabular}

SOURCE: Based on information contained in William G. Murray and Ronald C. Bentley, "The Iowa Farm Mortgage Problem," in The Agricultural Emergency in Iowa (Ames, Iowa: 1933), 56 and 62. Murray and Bentley used the ratio, 1:111, to estimate the State total from the figures in thirteen representative townships.

If the type of mortgage presents one possible measure of speculation, the source of loan money suggests another. During the period under consideration, two groups of investors, insurance companies and private individuals, provided about three-fourths of farm loans in Iowa. ${ }^{10}$ The insurance companies pursued decidedly cautious conduct. They would not accept junior mortgages nor would they take first mortgages which represented more than 50 per cent of the value of the land. ${ }^{11}$ As a result, although the cash value of their mortgage holdings steadily increased from 1915 until 1920, according to the thirteen township study, their share of the total mortgage market dropped from 22 per cent to 20 . At the same time, private investors, under no restraint, boosted their portion from 54 per cent to $61 .{ }^{12}$

The rapid plunge of farm prices in the autumn of 1920 brought an end to the rosy dreams of ever-ascending prices for agricultural land. Those who had speculated in 1919 on the basis of $\$ 1.50$ corn and $\$ 20.00$ hogs woke to the prospect of paying their debts with 50 cent corn and $\$ 7.00$ hogs. ${ }^{13} \mathrm{~A}$ great wave of foreclosures resulted. Whereas in the five year period, 1916-20, there had been an estimated $\$ 3,400,000$ of judgments in Iowa, the next five years brought $\$ 111,400,000$, with the peak year being 1924. A study of fifteen selected counties showed that private investors bought 61 per cent, in value, of these actions while insurance companies ac- 
counted for slightly less than 8 per cent. ${ }^{14}$ A dramatic drop after 1920 in the percentage of outstanding farm debt held by private investors suggests once again that speculators were cutting their losses while the more conservative insurance companies continued a steady rate of financing based on their view of solid investment. Federally chartered land banks, following policies similar to insurance companies, increased their share of the market from 2 per cent in 1920 to 12 per cent a decade later. ${ }^{15}$

TABLE II.-Estimated Value of lowa Farm Debt Held by Private Lenders and Insuranca Companies

\begin{tabular}{ccccc} 
& \multicolumn{2}{c}{ Percentage of Total } & \multicolumn{2}{c}{ Dollar Value } \\
\cline { 2 - 5 } $\begin{array}{c}\text { Year } \\
\text { (Dec. 31) }\end{array}$ & $\begin{array}{c}\text { Insurance } \\
\text { Companies }\end{array}$ & $\begin{array}{c}\text { Private } \\
\text { Lenders }\end{array}$ & $\begin{array}{c}\text { Insurance } \\
\text { Companies }\end{array}$ & $\begin{array}{c}\text { Private } \\
\text { Lenders }\end{array}$ \\
\hline 1915 & 22 & 54 & $150,725,000$ & $369,962,000$ \\
1920 & 20 & 61 & $299,915,000$ & $899,846,000$ \\
1925 & 32 & 43 & $489,981,000$ & $658,413,000$ \\
1930 & 39 & 32 & $493,529,000$ & $404,946,000$ \\
1932 & 42 & 27 & $454,810,000$ & $292,378,000$ \\
(Oct. 15) & & & & \\
\hline
\end{tabular}

SOURCE: Bạsed on information contained in William G. Murray and Ronald C. Bentley, "The Iowa Farm Mortgage Problem," in The Agricultural Emergency in Iowa (Ames, Iowa: 1933), 56 and 66. The same ratio used as in Table $\mathbf{I}$.

The great reduction of junior mortgages and the dramatic increase in the percentage of mortgages held by institutions cautiously selective in their loaning policies, together indicate that the truly speculative investors of $1917-20$ had fled the scene well before 1932. There is further evidence of this as well. Land speculation presupposes a high debt per acre. The gambler ventures little capital, but he must amortize the heavy interest charges and large principal payments through continued high prices and by an appreciation in land values. If the reverse case occurs, if prices collapse as in 1920, then interest payments lapse, and the capital advanced in speculation is lost.

Reasonable indebtedness of Iowa farm land during the years from 1915 to 1930 would have ranged from $\$ 50$ to $\$ 75$ per acre. ${ }^{15 n}$ The study of thirteen representative Iowa town- 
ships showed that 21.1 per cent of mortgaged farms in 1921 fell within this range as compared to 26.3 per cent in 1932 not a startling variance. In the higher, speculative ranges of indebtedness, however, there were striking contrasts. In 1932, only 15.1 per cent of farms mortgaged carried an encumbrance of over $\$ 100$ per acre, but eleven years earlier, when the effect of the boom was still current, the figure had been 41.3 per cent. And in the most ethereal realms of speculation, almost 10 per cent of farms mortgaged in 1921 had soared to above $\$ 200$ per acre debt; by 1932 debts on this level had been almost completely wiped out, sinking to a comparatively insignificant 1.4 per cent. ${ }^{16}$ The nature of the investment pattern is quite plain. During the period of high commodity prices, some farmers and other land buyers had encumbered themselves with mortgages that proved disastrously high after 1920; but by Oct. 1932, the overwhelming majority of farms mortgaged carried an indebtedness that cautious lenders had considered at an eminently safe level before the onset of the depression.

If judged by each of the three criteria-number of junior mortgages, source of money, and debts per acre mortgagedthen there obviously was speculation in Iowa farm land during the years, 1917-20. The downward spiral of commodity prices, beginning late in 1920 , brought in its wake a flood of foreclosures over the period of the next few years. After a peak in 1924, the volume of forced sales declined thereafter during every year but one until 1931. ${ }^{17}$ Most, if not all, of the speculators from the boom times gave up their deeds to Iowa farm lands and escaped from their earlier deals as best they could by the mid-twenties. Those who remained in possession were men who aimed primarily at making a reasonable living from the sale of their produce rather than profits from the appreciation in the value of their acres, and they were encouraged by the moderate increase in commodity prices which began in the autumn of 1924 .

Over the next five years, from 1925 through 1929, the exchange values of Iowa farm products fluctuated between 91 and 96 per cent of prewar. ${ }^{18}$ The golden level of parity was never equalled in other words, but it seemed within the realm of possible achievement. As a result, Iowa farmers 
bought thousands of tractors, trucks, and cars. They taxed themselves for new schools, and they expanded their network of roads until by 1932 only three others surpassed the Hawkeye State in miles of portland cement highways. ${ }^{19}$

Insurance companies did not change their loan policies during the nineteen-twenties. They hewed to the conservative line which had kept them relatively free from the speculative binge of the wartime years. They foreclosed on very few farms from 1921 to $1925 .{ }^{20}$ After 1.924, the insurance companies and the equally cautious land banks increased the volume of their loans to farmers. Since their guidelines had not changed, it must be assumed that they viewed Iowa mortgages as safe investments during the second half of the decade.

With the onset of the Great Depression most Iowa farmers found themselves in distress if not despair. But almost as deeply troubled were the insurance companies and land banks which were now forced to foreclose on the seemingly giltedged loans of a few years earlier. All the trusted economic guidelines of the past had gone haywire when the price of Iowa corn dropped from ninety cents a bushel in Sept. 1930 to twelve cents in Dec. two years later. ${ }^{21}$ By Dec. 31, 1932, insurance companies owned 4,308 Iowa farms. They had acquired almost 40 per cent of them during the preceding twelve months, and for the first time in history they had taken over at least one farm in each of the ninety-nine counties during the year. ${ }^{22}$ The easy explanation that farmers were suffering from their speculative greed of a dozen years earlier was simply not true. The conservative judgments of both borrower and lender did not apply in a world seized by economic irrationality.

\section{Notes}

${ }^{1}$ William G. Murray and Ronald C. Bentley, "The Iowa Farm Mortgage Problem," in The Agricultural Emergency in Iowa, (hereinafter referred to as Agricultural Emergency), Iowa Agricultural Experiment Station Reprint Series No. J 123 (Ames, Iowa: 1933), 56. 716 .

${ }^{2}$ USDA, Yearbook of Agriculture, 1934 (Washington, D. C.: 1934), 
${ }^{2 a}$ Lauren K. Soth, Agricultural Economic Facts Basebook of Iown (hereinafter referred to as Agricultural Basebook), Iowa Agricultural Experiment Station and Iowa Agricultural Extension Service Special Report No. 1 (Ames, Iowa: 1936), 119.

For an excellent account of Iowa farm unrest, see Frank D. Dileva, "Frantic Farmers Fight Law," "Iowa Farm Price Revolt," "Attempt to Hang An Iowa Judge," ANNALSS OF IOWA, XXXII (October 1953, January 1954, July 1954), 81-109, 171-202, 337-364.)

${ }^{3}$ William Allen White, "The Farmer Takes His Holiday," Saturday Evening Post, CCV (November 26, 1932), 68; Josephine Herbst, "Feet in the Grass Roots," Scribners, LXLIII (January, 1933), 46; Des Moines Register, October 7, 1932, p. 12. See also, "Editorial Paragraphs," Nation, CXXXVII (November 1, 1933), 497.

${ }^{4}$ George F. Warren and Frank A. Pearson, Prices (New York: 1933), 27.

${ }^{5}$ Soth, Agricultural Basebook, 116.

${ }^{6}$ Ibid., 117.

${ }^{7}$ Earle D. Ross, Iowa Agriculture: An Historical Survey (Iowa City, Iowa: 1951), 148-149.

${ }^{8}$ Donald R. Murphy to author, April 10, 1963.

9Murray and Bentley, "The Iowa Farm Mortgage Problem," 61-63.

${ }^{10}$ Ibid., 66.

${ }^{11}$ William G. Murray and Ronald C. Bentley, "Farm Mortgage Foreclosures," in Agricultural Emergency, 70.

${ }^{12}$ Murray and Bentley, "The Iowa Farm Mortgage Problem," 66. ${ }^{13}$ Soth, Agricultural Basebook, 26.

${ }^{14}$ Murray and Bentley, "Farm Mortgage Foreclosures," 88.

${ }^{15}$ Murray and Bentley, "The Iowa Farm Mortgage Problem," 66.

${ }_{15 a}$ «"The average debt load per acre in 1914, according to one Iowa study, had been $\$ 56$. Ibid., 59."

${ }^{16}$ Ibid., 60.

${ }^{17}$ Murray and Bentley, "Farm Mortgage Foreclosures," 88-89; Soth, Agricultural Basebook, 119.

${ }^{18} \mathrm{Ibid}$., 20 ; the years, $1910-14=100$. This compares to the range of 70 to 78 per cent from 1921 through 1924.

${ }^{19}$ Eugene G. McKibben and R. Austin Griffen, Changes in Farm Power and Equipment: Tractors, Trucks, and Automobiles, U. S. Works Progress Administration National Research Project Report No. A-9 (Philadelphia, Pa.: 1938), 78-84, 103; Lawrence Witt, Incoming and Outgoing Payments of Iowa Farm Families, Iowa Agricultural Experiment Station Research Bulletin No. 293 (Ames, Iowa: 1941), 416; John A. Hopkins, Jr., "The Iowa Tax Situation," in Agricultural Emergency, 21-32; USDA, Yearbook of Agriculture, 1934, 746.

${ }^{20}$ William G. Murray and Ronald C. Bentley, Corporate-Owned Land in Iowa, Iowa Agricultural Experiment Station Research Bulletin No. 307 (Ames, Iowa: 1933), 106.

${ }^{21}$ Soth, Agricultural Basebook, 26.

${ }^{22}$ Ibid., 112. 
Copyright of Annals of Iowa is the property of State of Iowa, by \& through the State Historical Society of Iowa and its content may not be copied or emailed to multiple sites or posted to a listserv without the copyright holder's express written permission. However, users may print, download, or email articles for individual use. 